\title{
BIOMASSES AND XYLANASE PRODUCTION BY STRAINS OF PENICILLIUM ISOLATED FROM BRAZILIAN ATLANTIC FOREST
}

\author{
S.M. Tauk-Tornisielo, M.C. Vallejo, J.S. Govone
}

Universidade Estadual Paulista, Centro de Estudos Ambientais, Av. 24A, 1515, CEP 13506-900, Rio Claro, SP, Brasil. E-mail: seb@rc.unesp.br

\begin{abstract}
Six Penicillium strains were isolated from soil at a depth of $0-15 \mathrm{~cm}$ in the Juréia-Itatins Ecology Station (JIES), in the São Paulo State, Brazil. They were evaluated for xylanase production under different temperatures and carbon sources. The best carbon source and temperature were first determined in an automated Bioscreen $C$ system, verifying the growth of microorganisms. Liquid media containing tap water with $2 \%$ carbohydrate and/or $1 \%$ nitrogen sources were used. Afterwards, Penicillium citrinum, P. fellutanum, P. rugulosumand $P$. decumbens were cultivated in $250 \mathrm{~mL}$ Erlenmeyer flasks with $50 \mathrm{~mL}$ of culture medium containing tap water sole $2 \%$ carbon source (fructose, glucose, mannitol, sucrose or xylose) and $1 \%$ yeast extract as a nitrogen source at $\mathrm{pH} 5.0$ and $28^{\circ} \mathrm{C}$, with agitation of $150 \mathrm{rpm}$ for 72 hours. These same strains, except $P$. decumbens, and P.purpurogenumwere cultivated in solid substrate with wheat bran under the same environmental conditions to study the potential of xylanase activity. Maximum xylanase activity was observed in cultures with wheat bran, without the addition of any other carbon source, using inocula containing $1 \times 10^{7}$ spores. $\mathrm{mL}^{-1}$ $\left(28^{\circ} \mathrm{C}, \mathrm{pH} 5.0,72 \mathrm{~h}\right)$. It can be concluded that $P$. fellutanum and $P$. citrinumare a good xylanase producers under the conditions of $28^{\circ} \mathrm{C}$. The results of xylanase activity were $54 \%$ less at $28^{\circ}$ $\mathrm{C}$ in liquid cultures media cultures than in solid substrate.
\end{abstract}

KEY WORDS: Penicillium, xylanase activity, wheat bran, carbon source, liquid culture, solid substrate.

RESUMO

BIOMASSA EPRODUÇÃODAXILANASEPOR LINHAGENSDEPENICILLIUMISOLADASDA MATA ATLÂNTICA. Seis linhagens de Penicillium foram isoladas do solo, na profundidade de 0 - 15 cm, na Estação Ecológica de Juréia-Itatins (EEJI), Estado de São Paulo, Brasil. Elas foram analisadas quanto a produção de xilanase sob diferentes temperaturas e fontes de carbono e de nitrogênio. Foi utilizado meio contendo água de torneira com $2 \%$ de carboidrato e/ ou $1 \%$ de fonte de nitrogênio. A melhor fonte de carbono e temperatura foram obtidas no sistema automatizado de crescimento tipo Bioscreen C. Posteriormente, Penicillium citrinum, P. fellutanum, P. rugulosum e $P$. decumbens foram cultivadas em frascos agitados em $150 \mathrm{rpm}$, contendo meio líquido contendo água de torneira com uma única fonte de carbono $2 \%$ e/ ou $1 \%$ de fonte de nitrogênio, pH 5.0, a $25^{\circ} \mathrm{C}$, por 72 horas. Estas mesmas linhagens, exceto P. decumbens, e P. purpurogenum foram cultivadas em substrato sólido contendo farelo de trigo sob as mesmas condições ambientais anteriores de cultivo. Maior atividade de xilanase foi observada em culturas contendo farelo de trigo, sem adição de qualquer outra fonte de carbono, usando inoculo com $1.10^{7}$ esporos $\mathrm{mL}^{-1}\left(25^{\circ}\right.$ $\mathrm{C}, \mathrm{pH} 5.0,72$ h). Pode ser concluído que $P$. fellutanum $P$. citrinum são bons produtores de xilanase a $28^{\circ} \mathrm{C}$. Os resultados da atividade da xilanase foram $54 \%$ menores a $28^{\circ} \mathrm{C}$ em cultura líquida em relação aos resultados observados em substrato sólido.

PALAVRAS-CHAVE: Penicillium, atividade da xilanase, farelo de trigo, fonte de carbono, cultura líquida, substrato sólido.

\section{INTRODUCTION}

The Atlantic Rainforest represents one of the most degraded ecosystems in Brazil. Remaining forested areas have been declared protected areas to guarantee the preservation of the fauna and flora. One of these protected areas is the Juréia-Itatins Ecology Station (JIES), in the state of São Paulo, Brazil. Previous studies have documented the occurrence of filamentous fungi in the soil in primary and secondary forests of the JIES, 
and the potential of the isolated species to produce enzymes of significant industrial importance (TAUKTORNISIELO et al., 2005).

Xylanase $(1,4-\beta$-D-xylan xylanodydrolase EC 3.2.1.8) is the major component in a $\beta x y$ losidases that act to depolymerize the xylan molecules into monomers, which can be used by bacteria and fungi as a primary source of sugar. Xylanase is one of the microbial extracellular enzymes that has attracted great interest due to its biotechnological potential in many industrial processes, e.g., in the production of oligosaccharides (PELLerin et al., 1991); in the food industry (HALTRICH et al., 1996); cellulose and paper industry (YAUN; RugYU, 1999); xylitol and ethanol production (BEG et al., 2001); cellular proteins, liquid fuels, and other chemical substances (CHAN et al., 2002). Xylanases catalyze xylanhydrolysis, and many environmental factors affect production of these enzymes, but carbon source can induce or repress the catabolic activity of them, which can this enzyme biosynthesis, such as: temperature and cultivation time (Haltrich et al., 1996); and substrate used (LenARTOVICZ et al., 2002; 2003).

The objective of this study was to evaluate the cultivation conditions for the increase of biomasses and of xylanase activity by differentPenicillium strains, verifying the effect of carbon sources and temperatures. These strains were isolated from soil in the "Banhado Grande" area of the JIES (TAUK-ToRnISIELOet al., 2005).

\section{MATERIAL AND METHODS}

\section{Isolation and inocula}

The Penicillium strains (P. citrinum, P. decumbens, $P$. fellutanum, P. purpurogenum, and P. rugulosum) were isolated from the soil $(0-15 \mathrm{~cm}$ deep) in the JuréiaItatins Ecology Station (JIES), São Paulo state, Brazil, and stored at $4^{\circ} \mathrm{C}$ in test tubes containing malt extract medium (Merck). Concentration of $10^{6}$ to $10^{7}$ spores.mL $L^{-1}$ was used as inocula in this study, after counting in a Neubauer chamber (Improved BrightLine-Levy-Chamber, Cat. Nr. 500 Batch Counting Chamber, Hausser Scientific, 1/400SQmm, profundity $1.10 \mathrm{~mm}^{-1}$ ), in a $0.85 \% \mathrm{NaCl}$ solution.

\section{Bioscreen C technique}

The strains were cultivated in the Bioscreen C automated system (Lab systems Helsinki, Finland), using a culture medium with tap water and $2 \%$ single carbon source and/or $1 \%$ single nitrogen source. The carbon sources used were fructose, galactose, glycerol, glucose, lactose, maltose, mannitol, sucrose or xylose. The nitrogen sources included yeast extract, peptone, ammonium sulfate, or potassium nitrate. In theculture media with tap water and a single nitrogen source, $2 \%$ glucose was used as the carbon source. The working volume in the wells of the Bioscreen plate was $400 \mu \mathrm{L}$, comprised of $360 \mu \mathrm{L}$ culture medium and $40 \mu \mathrm{L}$ spore solution. The temperature was controlled at $28^{\circ} \mathrm{C}$ or $45^{\circ} \mathrm{C}$, and the optical density of the cell suspensions was measured automatically at $540 \mathrm{~nm}$ at regular intervals of $2 \mathrm{~h}$ for a period of five days. Before each measurement, the culture wells were automatically shaken for 60 seconds. The experiments were carried out in quadruplicate and the results are represented by mean values observed in the four repetitions of each culture medium used.

The control tubes contained the culture medium being tested without inoculum. The data were analyzed in spreadsheet software (Excel 97), calculating the averages of the quadruplicates for each type of culture medium. The averages were used to generate the growth curves for each strain studied, constructed as a function of the incubation time and the absorbance of the culture medium, with the data plotted in 20-hour intervals. The results were submitted to the Friedman Test (ZAR, 1999), with $5 \%$ significance level.

\section{Fungi cultures and xylanase activity}

The Penicillium strains were cultured in liquid medium containing $2 \%$ carbon source (fructose, glucose, mannitol, sucrose or xylose) and $1 \%$ yeast extract as a nitrogen source in $250 \mathrm{~mL}$ Erlenmeyer flasks with $50 \mathrm{~mL}$ of tap water. Each flask was inoculated with $1 \mathrm{~mL}$ freshly prepared spore suspension, $1.10^{7}$ spores.mL $\mathrm{mL}^{-1}$. Tested in BioScreen C system showed better growth of strains in the temperature of $28^{\circ} \mathrm{C}$. Then, the cultures were agitated continuously at $150 \mathrm{rpm}$, at $28^{\circ} \mathrm{C}$, for $72 \mathrm{~h}$ incentrifuge Jouan model GR20 2220 (Jouan BR-4i, France). Following this period, the biomass produced in submerged culture was separated using vacuum filtration in No. 1 Whatman filter paper. The biomass was washed thoroughly three timesin distilled water and the remaining liquid was removed, and thefiltered biomass placed between sheets of dry filter paper (Simões; TAuK-Tornisielo, 2005). The wet biomass was placed in pre-weighed beakers at $105^{\circ} \mathrm{C}$ for $48 \mathrm{~h}$ to determine the dry weight.

The solis substrate was done with $5 \mathrm{~g}$ wheat bran and $5 \mathrm{mLErlenmeyerflask,} \mathrm{and} \mathrm{the} \mathrm{pHadjusted} \mathrm{to} \mathrm{5.5.}$ The media were homogenized using a spatula. The flasks were covered and autoclaved at $121^{\circ} \mathrm{C}$ for 30 $\mathrm{min}$, after which they were inoculated.Concentration of $10^{6}$ to $10^{7}$ spores. $\mathrm{mL}^{-1}$ was used as inocula in this study, after counting in a Neubauer chamber (improved bright-line-levy-chamber, cat. nr. 500 batch 
counting chamber, hausser scientific, $1 / 400$ sqmm, profundity $\left.1.10 \mathrm{~mm}^{-1}\right), 0.85 \%$ in a $\mathrm{NaCl}$ solution. These same conditions were used to prepare flasks with the best carbon source, determined by the Bioscreen C system.

After the incubation in solid state at $28^{\circ} \mathrm{C}, 30 \mathrm{~mL}$ of sterilized distilled water were added to the flasks. The cultures were homogenized, and the flasks were maintained at $4^{\circ} \mathrm{C}$ for $3 \mathrm{~h}$, then the cultures were filtered under vacuum. The biomass obtained in submerged culture medium was also filtered using the same methodology, and the filtrates were considered as gross enzyme extract (LinKoetal.,1978). The determination of xylanase activity was carried out after 10 or 20 min at $50^{\circ} \mathrm{C}$, using Birchwood Xylan Sigma, U.S. (BAILEY et al., 1992) $1 \%(\mathrm{w} / \mathrm{v})$ in sodium acetate buffer 50 mmol.L (pH 5.0). The release of the reducing sugars was determined by the dinitrosalicylic acid method (ADNS) (MILLER, 1959). Oneunitof enzyme activity ( $U$ ) was defined as the amount of enzyme necessary to produce $1 \mu \mathrm{mol} \mathrm{mL}{ }^{-1} \mathrm{~min}^{-1}$ of glucose or xylose under the assay conditions. The protein concentration was determined by Lowry's method (Lowry et al., 1951), using bovine serum albumin as the standard, in triplicate, using appropriate blanks.

The results were analyzed using the KruskalWallis statistical test $\left(Z_{A R}, 1999\right)$ to check for a possible relation between the different carbon sources used and xylanase activity of the variousPenicillium strains studied here.

\section{RESULTS AND DISCUSSION}

Through the experiments carried out in the automated Bioscreen C system, 240 growth curves were obtained for the six strains of Penicillium in media containing sole of carbon and/or nitrogen source. The best growth curves were obtained at a temperature of $28^{\circ} \mathrm{C}$, especially for $P$. citrinum in

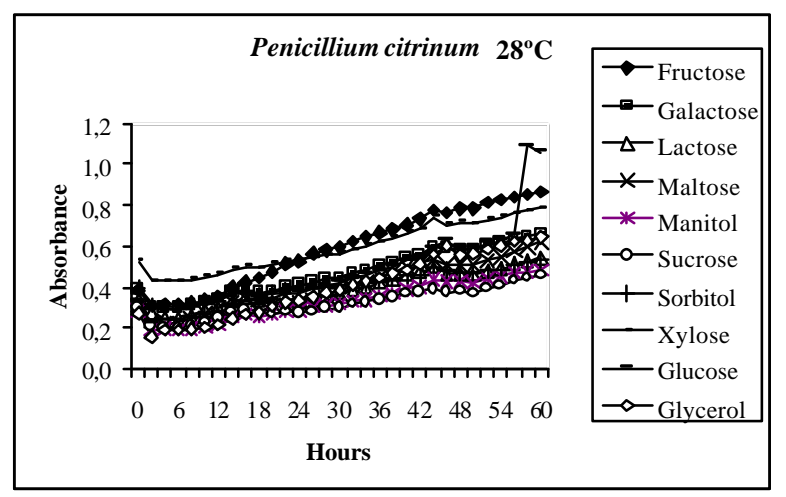

Fig. 1 - Growth curves of Penicillium citrinum in media containing sole carbon source indicated, incubated at $28^{\circ}$ C for 60 hours, in an automated Bioscreen C system. different carbon source and yeast extract (Fig. 1), but few strains could grow in the different media at $45^{\circ} \mathrm{C}$. However, good growth of P. fellutanum was verified at a temperature of $45^{\circ} \mathrm{C}$ (Fig. 2).

Good growth of each strain of Penicillium was dependent on the carbon or nitrogen source added to the medium. The strains of $P$. citrinum, $P$. fellutanum and $P$. rugulosum had better growth in media with fructose, glucose and sucrose as the solecarbon source, but only fructose caused better results for theP.citrinum at $28^{\circ} \mathrm{C}$ (Fig. 1) and P. fellutanum at $45^{\circ} \mathrm{C}$ (Fig. 2). All strains needed yeast extract as nitrogen source for good growth, and the other nitrogen sources used here contributed very little to increase growth of the strains.

For each type of culture, the use of its respective control served to observe any type of secondary contamination and to provide a correct interpretation of the microorganisms' growth in the culture medium. The possibility of contamination may result from the speed of filamentous fungi growth, which is usually low in relation to the yeasts and bacteria. The maximum number of bacteria or yeast can occur at 6 hours of cultivation, due to their ability to grow easily and rapidly in liquid culture media (JOHNSTON, 1998). The strains studied here begin their log phase at approximately $60 \mathrm{~h}$ of culture.

The use of an automated system like Bioscreen C was very appropriate for cultures in liquid media, proving to bea good technique to determinetheoptimal environmental factors for growth of the filamentous fungi.

In the assays using submerged cultures of the different species of Penicillium, the best nitrogen and carbon sources identified by the automated system Bioscreen C were used. The yeast extract was not only the best nitrogen source, but no strain grew in media without the addition of this nutritional source. The biomasses quantities were determined ing (dry mass) per liter of culture medium, after $72 \mathrm{~h}$ (Table 1).

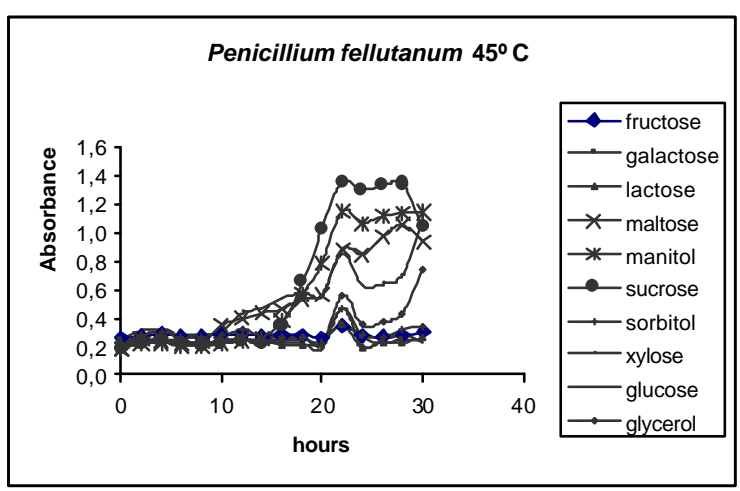

Fig. 2 -Growth curves of Penicillium fellutanumin medium containing sole carbon source indicated, incubated at $45^{\circ}$ $\mathrm{C}$ for 60 hours, in an automated Bioscreen $\mathrm{C}$ system. 
Table 1 - Biomasses production (g. $\mathrm{L}^{-1}$ - dry weight) in liquid culture containing sole carbon source and yeast extract at $28^{\circ} \mathrm{C}$.

\begin{tabular}{lcccc}
\hline Carbon source & P. citrinum & P. fellutanum & P. rugulosum & P. decumbens \\
\hline Fructose & 3.7 & 7.4 & 2.0 & 3.2 \\
Glucose & 4.0 & 4.5 & 2.1 & 3.0 \\
Mannitol & $1.0-$ & 1.1 & 3.0 & $0.5-$ \\
Sucrose & 3.6 & 7.8 & 3.3 & 2.0 \\
Xylose & 2.3 & 2.0 & 2.2 & $1.0-$ \\
\hline
\end{tabular}

Table 2 - Activity of xylanase $\left(\mathrm{U} \cdot \mathrm{mL}^{-1} \cdot \mathrm{h}^{-1}\right)$ at 10 and 20 minutes of reaction from the strains of Penicilliumin liquid cultures at $28^{\circ} \mathrm{C}$. Legend: $\mathrm{nd}=$ xylanase activity not determined.

\begin{tabular}{|c|c|c|c|c|c|c|c|c|c|c|}
\hline \multirow[t]{2}{*}{ Culture media } & \multicolumn{2}{|c|}{ P. citrinum } & \multicolumn{2}{|c|}{ P. fellutanum } & \multicolumn{2}{|c|}{ P. decumbens } & \multicolumn{2}{|c|}{ P. rugulosum } & \multicolumn{2}{|c|}{ P. purpurogenum } \\
\hline & $10 \mathrm{~min}$ & $20 \mathrm{~min}$ & $10 \mathrm{~min}$ & $20 \mathrm{~min}$ & $10 \mathrm{~min}$ & $20 \mathrm{~min}$ & $10 \mathrm{~min}$ & $20 \mathrm{~min}$ & $10 \mathrm{~min}$ & $20 \mathrm{~min}$ \\
\hline Fructose & 18.2 & 13.6 & 26.5 & 17.9 & 4.2 & 3.6 & 1.8 & 1.5 & 1.4 & 1.0 \\
\hline Glucosa & 10.0 & 7.7 & 15.2 & 9.6 & 9.2 & 5.5 & 1.2 & 0.8 & 2.4 & 1.3 \\
\hline Mannitol & nd & nd & nd & nd & nd & nd & 2.1 & 1.0 & nd & nd \\
\hline Sucrose & 1.4 & 0.3 & 2.4 & 0.7 & nd & nd & nd & nd & nd & nd \\
\hline Xylose & 0.6 & 0.1 & 2.7 & 0.8 & nd & nd & nd & nd & nd & nd \\
\hline
\end{tabular}

No similarity was observed between the results obtained in an automated system and those obtained from submerged cultures in agitated flasks. In the automated system, growth of $P$. fellutanum and $P$. rugulosum was observed at $45^{\circ} \mathrm{C}$, but this same result couldnotbeverified insubmerged cultures, independently of the carbon or nitrogen source added to the culture media. The best biomass production was observed in the culture of $P$. fellutanum in media with fructose or sucrose, as sole carbon source and added yeast extract, at $28^{\circ} \mathrm{C}$. In medium containing mannitol, under the same cultivation conditions, $P$. rugulosum was the only grown (Table1). The results of xylanase activities in the liquid cultures are cited in Table 2. Therefore, higher xylanase activity was obtained in solid substrate containing wheat bran as the carbon source being 39.4 U.mL ${ }^{-1}$ in culture of P. fellutanum, 36.7 U.mL ${ }^{-1}$ in culture of $P$. citrinum, and. 26.1 U.mL ${ }^{-1}$ in culture of $P$. decumbens. In cultures of the other strains, the xylanase activity was lesser.

Statistical analysis was performed with two hypotheses $\mathrm{H} 0=$ no differences between the activities of the enzyme in relation to the media used and H1 differences between the activities. It accepts the hypothesis $\mathrm{H} 1$, ie, there were statistically significant differences to $5 \%$ by Kruskal-Wallis test (ZAR, 1999; AYres et al., 2005) between the groups: mannitol (a), xylose (a), sucrose (b), glucose (bc) and fructose (c) and wheat bran (c). So, with 4 different groups in terms of culture used here fructose and wheat bran gave better results.
The second question is hypotheses $\mathrm{H} 0=$ no differences between the strains in the production of enzymeand $\mathrm{H} 1=$ therearedifferencesintheproduction of enzyme. Accept H0, or there was no statistically significant difference at $5 \%$ between the strains in enzymatic activity with Kruskal-Wallis test. Theother question considered $\mathrm{HO}=$ no differences in values of biomass between the lines and culture media used here, and $\mathrm{H} 1$ = statistically significant differences. Accept H0, so there was no statistically significant difference at 5\% level, in Kruskal-Wallis test. There was a possible correlation of Pearson equal to 0625 significant at $5 \%$ probability by the Student t-test, between the production of biomass and activity of enzymes in different ways and for different species. Then when the Kruskal-Wallis test (ZAR, 1999; A YRES et al., 2005) was applied to comparePenicillium strains grown in media containing different carbon sources, no statistically significant differences were found. A possible correlation was also found behind biomass production and xylanase activity in different media and Penicillium strains.

Although the xylanase activity was higher in solid substrate with cultivation of $P$. citrinum, $P$. fellutanum and $P$. decumbens, in liquid culture in medium containing glucose or fructose as solecarbon source, the best results were found for other cultures (Table 2). These values were lower than those obtained with Aspergillus japonicus, 143.9 and 18.3 U.mL-1, in media with sucrose and fructose respectively, under the same cultivation conditions 
(Simões; Tauk-Tornisielo, 2005). However, mechanisms of synthesis control vary considerably among microorganisms (DE VRIES et al., 2000). In culture of Streptomyces A-151, low efficiency of xylanase production was observed after the addition of other carbon sources in cultures using rice bran (WANG et al., 2003), which corroborates findings reported by other authors (BAKIR et al., 2001; RANI; NAND, 2001; Chan et al., 2002).

Xylanase produced by Humícula lanuginosa was approximately 23-fold higher in solid substrate than in submerged culture (KAMRA;SATYANARAYANA, 2004). Better xylanase production was observed in cultures of fungi in solid substrate (KHENG;IBRAHIM, 2005; S HAH; MADAMWAR, 2005), and the same was verified for other enzymes such as endoglucanases and $\beta$-glucosidades (GRAJEK, 1987), a-amylases (LONSANE; RAMESH, 1992) and pectinases produced by A. niger (ACUNÃArguelles et al., 1995).

Many authors reported the advantages of using wheat bran as a substrate for xylanase production in solid-substrate when compared to other solid wastes (SouzA et al., 2001). The highest xylanase production with wheat bran was possible because this substrate is rich in proteins and hemicelluloses, which are used by microorganisms as sources of energy and carbon, through specific enzymes such as xylanase. Wheat bran, among other substrates used in solid systems, is the most efficient, because it does not perform catabolic repression on the enzymatic activity (LENARTOVICZ et al., 2002).

When the xylanase activity was measured at 10 min of reaction, it always presented higher values in relation to those obtained after 20 min of reaction time, except for $P$. decumbens, being the results, represented here by means of four replicates.

After several experiments with different temperature, it was found that for liquid culture the best xylanase activity occurred at $28^{\circ} \mathrm{C}$. Xylanase production by Aspergillus japonicus was tested at four different temperatures $\left(20^{\circ} \mathrm{C}, 28^{\circ} \mathrm{C}, 35^{\circ} \mathrm{C}\right.$, and $\left.40^{\circ} \mathrm{C}\right)$ and $28^{\circ} \mathrm{C}$ was the best temperature for xylanase production $(143.9 \mathrm{U} / \mathrm{mL})$; this was two-fold higher than the activity obtained at $20^{\circ} \mathrm{C}$ and 5-fold higher than that observed at $35^{\circ} \mathrm{C}$, and was extremely low at $40^{\circ}$ C (Simões; Tauk-Tornisielo, 2005). The results obtained here are similar to those obtained by other authors who established that the best temperature range for xylanase activity is between $20^{\circ} \mathrm{C}$ and $30^{\circ} \mathrm{C}$ (HAQ et al., 2005). However, the best growth temperature for the fungus is not always the best for enzyme activity. According to RAHMAN et al. (2003) and YAun et al. (2005), the large decreases at very low or high temperatures are because the fungal growth is inhibited at these temperatures, leading to a decrease in enzyme synthesis.
The best xylanase activity (234.56 U.mL $\left.{ }^{-1}\right)$ by Trichoderma viride was obtained when cultivated in wheat bran with added with $1 \%$ sorbitol (v/w) ( $\mathrm{pH} 5.0$, $\left.25^{\circ} \mathrm{C}, 144 \mathrm{~h}\right)$ using inoculum. The results obtained indicate a significant increase in xylanase production with the use of nutrients. Sorbitol and temperature $\left(25^{\circ} \mathrm{C}\right)$ were determined to be the best inducers for $T$. viride growth (unpublished data). This strain had better xylanase activity results than Aspergillus japonicus, under the same growth conditions, but with inoculum having lower spore concentration and longer cultivation time. The results with the six strains of Penicillium were lower (Table2) than those obtained with T. viride or A japonicus, however they were obtained in media containing wheat bran without addition of any another nutritional source.

\section{ACKNOWLEDGEMENTS}

We would like to thank FAPESP for the Scientific Initiation scholarship granted to one of the authors, and FUNDUNESP for supporting the research.

\section{REFERENCES}

ACUNÃ-ARGUELLES, M.E.; GUTIÉRREZ-ROJAS, M.; VINIEGREA-GONZÁLEZ, G.; FAVELA-TORRES, E. Production and properties of three pectinolytic activities produced by Aspergillus niger in submerged and solid-state cultivation. Applied Microbiology and Biotechnology, v.43, p.808-814, 1995.

AYRES, M.; AYRES J.R., M.; AYRES, D.L.; SANTOS, A.S.dos. BioEstat 4.0. Aplicações estatísticas nas áreas das ciências biológicas e médicas. Belém: Sociedade Civil Mamirauá/ MCT/Imprensa Oficial do Estado do Pará, 2005.

BAILEY, M.J.; BIELY, P.; POUTANEN, K. Interlaboratory testing of methods for assay of xylanase activity. Journal of Biotechnology, v.23, p.257271, 1992.

BAKIR, U.; YAVASCAOGLU, S.; GUVENC, F.; ERSAYIN, A. An endo- $\beta-1,4-x y l a n a s e$ from Rhizopus oryzae. Production, partial purification and biochemical characterization. Enzyme and Microbial Technology, v.29, p.328-334, 2001.

BEG, Q.K.; KAPOOR, M.; MAHAJAN, L.; HOONDAL, G.S. Microbial xylanases and their industrial applications. Applied Microbiology and Biotechnology, v.56, p.326-338, 2001.

CHAN, A.Y.; CHAN, M.J.; LO, H.M.; LEUNG, Y.C.; LIM, B.L. A dual protein expression system in Bacillus subtilis. Protein Expression and Purification, v.26, p.337-342, 2002. DE VRIES, R.P; KESTER, H.C.M.; POULSEN, C.H.; 
BENEN, G.A.E.; VISSER, J. Synergy between enzymes from Aspergillus involved in the degradation of plant cell wall polysaccharides. Carbohydrate Research, v.327, p.401-410, 2000.

GRAJEK, W. Comparative studies on the production of cellulases by thermophilic fungi in submerged and solid-state fermentation. Applied Microbiology and Biotechnology, v.26, p.126-129, 1987.

HAQ, I.; KHAN, A.; BUTT, W.A.; ALI, S.; QADEER, M.A. Effect of carbon sources on xylanase production by mutant strain of Aspergillus niger GCBMX-45 International Journal of Agriculture and Biology, v.55, p.115-119, 2005.

HALTRICH, D.; NIDETZKY, B.; KULBE, K.D.; STEINER, W.; ZUPANCIC, S. Production of fungal xylanases. Bioresearch Technology, v.58, p.137-161, 1996.

JOHNSTON, M.D. A simple and rapid test for quality control of liquid media, using the bioscreen microbiological growth analyzer. Journal of Microbiological Methods, v.32, p.37-43, 1998.

KAMRA, P.; SATYANARAYANA, T. Xylanase production by the thermophilic mold Humicola lanuginosa in solid-state cultivation. Applied Biochemistry and Biotechnology, v.119, p.145-158, 2004.

KHENG, P.P.; IBRAHIM, C.O. Xylanase production via solid-state cultivation. Songklanakarin Journal Science Technology, v.27, p.332 - 335, 2005.

LENARTOVICZ, V.; SOUZA, C.G.M.; MOREIRA, F.G.; PERALTA, R.M. Temperature affects the production of multiple xylanases by Aspergillus fumigatus. Journal of Basic Microbiology, v.42, p.390-397, 2002.

LENARTOVICZ, V.; DE SOUZA, C.G.M.; MOREIRA, R.M.P. Temperature and carbon source affect the production and secretion of a thermostable bxylosidase by Aspergillus fumigatus. Process Biochemistry, v.38, p.1775-1780, 2003.

LINKO, M.; MARKKANEN, R.; BAILEY, M.; LEISOLA, M. Production of cellulases and hemicellulases by Trichoderma viride. In: GHOSE, T.K. (Ed.). Proceedings of the symposium on bioconversion of cellulosic substances into energy, chemicals and microbial proteins. New Delhi: Thompson Press, 1978. p.329-350.

LONSANE, B.K.; RAMESH, M.V. Production of bacterial thermostable enzymes by solid-state cultivation: a potential tool for achieving economy in enzyme production. Advances Applied Microbiology, v.15, p.1-48, 1992.

LOWRY, O.H.; ROSEBROUGH, N.J.; FARR, A.L.; RANDALL, R.J. Protein measurement with the Folin phenol reagent. Journal of Biological Chemistry, v.193, p.265-275, 1951.
MILLER, G.L. Use of dinitrosalicylic acid reagent for determination of reducing sugar. Analytical Chemistry, v.31, p.426-428, 1959.

PELLERIN, P.; GROSSELIN, M.; LEPOUTRE, J.; SAMAIN, E.; DEBEIRE, P. Enzymic production of oligosaccharides from corncob xylan. Enzyme and Microbial Technology, v.13, p.617-621, 1991.

RAHMAN, A.K.; SUGITANI, N.; HATSU, M.; TAKAMIZAWA, K. A role of xylanase, alphaarabinofuranosidase, and xylosidase in xylan degradation. Canadian Journal of Microbiology, v.49, p.5864, 2003.

RANI, D.S.; NAND, K. Purification and characterization of xylanolytic enzymes of a cellulosefree thermophilic strain of Clostridium absonum CFR702. Anaerobe, v.7, p.45-53, 2001.

SHAH, A.R.; MADAMWAR, D. Xylanase production by a newly isolated Aspergillus foetidus strain and its characterization. Process Biochemistry, v.40, p.1763-1771, 2005.

SIMÕES, M.L.G.; TAUK-TORNISIELO, S.M.

Optimization of xylanase biosynthesis by Aspergillus japonicus isolated from a "Caatinga" area in the Brazilian state of Bahia. African Journal of Biotechnology, v.5, p.1136-1141, 2005.

SOUZA, D.F.de; SOUZA, C.G.M. de; PERALTA, R.M. Effect of easily metabolizable sugars in the production of xylanase by Aspergillus tamarii in solid-state cultivation. Process Biochemistry, v.36, p.835-838, 2001.

TAUK-TORNISIELO, S.M.; GARLIPP, A.; RUEGGER, M.J.S.; ATTILI, D.S.; MALAGUTTI, E.N. Soilborne filamentous fungi in Brazil. Journal of Basic Microbiology, v.45, p.72-82, 2005.

WANG, S.L.; WEN, Y.H.; SHIH, I.L.; CHANG, A.C.; CHANG, W.T.; WU, W.T.; CHAI, Y.D. Production of xylanases from rice grain by Streptomyces actuosus A-151. Enzyme and Microbial Technology, v.33, p.917-025, 2003.

YAUN, Q.; RUGYU, M. Study on temperature oscillation in production of xylanase by Aspergillus niger. Beijing Hugagong Daxue Xuebao, v.26, p.11-13, 1999.

YAUN, Q.; WANG, J.; ZHANG, H.; QIAN, Z. Effect of temperature shift on production of xylanase by Aspergillus niger. Process Biochemistry, v.40, p.3255-3257, 2005.

ZAR, J.H. Biostatistical Analysis. 4.ed. New Jersey: Prentice Hall, 1999. 929p.

Received on $15 / 10 / 07$

Accepted on 4/5/09 